\title{
The Impact of Human Values on Ethical Climate: A Private Hospital Practice
}

\author{
Ali Arslanoglu (D), Hasan Giray Ankara $\mathbb{D}$ \\ University of Health Sciences, Hamidiye Faculty of Health Sciences, Department of Health Management, Istanbul, Turkey \\ Correspondence Author: Ali Arslanoglu \\ E-mail: aliarslanoglu18@gmail.com \\ Received: $03.12 .2020 \quad$ Accepted: 15.03 .2021
}

\begin{abstract}
Objective: The aim of this study was to identify the impact of human values on ethical climate. The study also explores the factors affecting either human values or ethical climate.

Methods: The study exploited the data of the staff in a private hospital operating in Istanbul. Accordingly, the data of 178 individuals was obtained in four weeks period starting from March 2019. Human values were measured by Human Values Scale which was validated by Dilmaç (2007). Ethical climate was measured by Ethical Climate Scale which was introduced by Schwepker (2001) and validated by Eren and Hayatoğlu (2011). The study employed one-way variance analyses and Kruskal Wallis tests to understand the variations in human values and ethical climate perception upon socioeconomic factors. Additionally, ordinary least square regression was performed to identify the effect of human values on ethical climate perception.

Results: It was found that better human values were associated with increasing perceptions of ethical climate. Further, the number of children, age and the length of service had considerable impacts on both human values and the perception of ethical climate. Finally, marital status and educational status did not have any significant impacts on human values and ethical climate.

Conclusion: It was identified that the people with better human values were more careful about ethical rules. The findings are important to understand the motivations of ethical climate in a competitive atmosphere. It is believed that further studies investigating ethical climates in public and private organisations comparatively will contribute to the literature.
\end{abstract}

Keywords: Human Values, Ethical Climate, Values

\section{INTRODUCTION}

Living in a peaceful society is mostly depend on the harmony between cultural values and the behaviours of the individuals. The values direct attitudes towards people and issues. It is highly possible to experience abuses, iniquities and violence if humanitarian values are not reflected in the behaviours (1). Hence, it can be said that the values have important roles in behavioural attitudes of the individuals. In addition to these, the values considerably enhance not only the vision but also the perception of individuals (2).

The values have been explained in a various way so far. For instance, they have been entitled as the fundamental notion determining the judgement of truth or goodness (3). They have been described as the fact that ensures analysing the issues and determining the behaviours (3). The values have been explained as a concept of organising human-nature and human-human relationships through the judgement of the things desired (and undesired) and determining human behaviours (4). The values have also been described as principles, believes or assets enlighten the preferences about the meaning of the life and shaping the daily life (5). There has been a great deal that the values are not only ideas as beliefs, but also are related to emotions $(3,5,6)$. They intertwine with emotions when they gain effectiveness. They are closely related to the aims of individuals and their behaviours in achieving those aims. It can be said that the values are above actions and situations. They function as standards for selecting, changing and directing people, behaviours and events. They can be ranked among themselves according to the importance of their own. Therefore, individuals and cultures can be described according to their priorities of values.

Everything in a society is perceived and compared according to values. People generally adopt the values of the group, society or culture they live in. Besides, they use these values as criteria in their judgements and choices. Thus, they have opportunity to have general judgements like better, more 
appropriate, more accurate, more beautiful, more important and fairer (7).

Ethic means a set of rules and principles or a set of moral principles or behaviours those are accepted socially or individually. From a broader perspective, ethic is the knowledge of what to do (or not to do), what to want (or not to want) and what to have (or not to have) (8). The concept of ethic, that has derived from the Greek word "ethos", is a set of measures examining the values, norms and rules those form individual and social relationships (9).

Ethical issues in terms of business are converged in four categories (10): relations, products, actions and staff. The relations with stakeholders and other partners are gathered in relations category. Products category includes the issues about environmental health, the use of resources and social purposes of the products. Actions category interests in commitments with the values such as truth, honesty, altruism and openness. Finally, staff category bears the issues about the variations of power, wage and ethnic origin among the staff.

Ethical climate is formed by ethical principles and behaviours. It refers the expected behaviours from staff in an organisation. It is originated from human values, policies and actions (11). Ethical climate not only demonstrates the right behaviour but also helps to make the required action in case of ethical issues (12). The frequency of practising expected behaviours among the employees implies that ethical climate is accepted to such an extent (13).

Humanitarian values are generally described as abstract ideals that direct behaviours (14). The impacts of behaviours on organisational climate have been of interest for the last thirty years (15). Human values and ethical climate have important roles in organisations since they (i) promote personal and interpersonal behaviours of the leaders, (ii) contribute to protect fundamental responsibilities and (iii) maintain continuous expansion and improvement of competence (16). Due to their importance in the organisations, this study examines the impacts of human values on the perception of ethical climate. In addition, the study identifies the factors affecting human values and ethical climate perception respectively. By doing this, the study aims to contribute to broader literature investigating the ethical climate by providing the findings from a competitive environment as the study exploits the data obtained from a private hospital operating in İstanbul, Turkey.

There are various studies in the literature examined the ethical climate from different perspectives. Dodd et al. (2018) state that directors who act as servant leaders are more likely to create an ethical work environment in their departments and to be role models that care about the well-being of their followers. It is also highlighted that they prioritize ethical behaviours and positively affect the behaviours of other staff (17). Günel et al. (2015) confirm that ethical leadership positively impacts ethical climate. Soffian Lee et al. (2018) indicate that benevolent and principled climates are positively and significantly associated with organizational commitments (18). Mitonga-Monga and Cilliers (2015) suggest that developing and maintaining a positive ethical climate in an organisation may increase the energy, mental flexibility and the permanence of the staff (19). Amer (2019) highlights that health professionals need greater awareness and training to increase their skills in ethics of integrity and their communication skills, especially in telling the patient the truth about diagnosis and treatment outcomes. Amer (2019) adds that these skills are important as they improve doctor-patient relationships, patients' care satisfaction and patients' health outcomes (20).

Oppong (2019) examines whether ethical decisions and actions are more likely to differ across cultural zone and time, despite the existence of "universal" normative ethical principles. He concludes that values are linked to cultural context within a universal dimension based on common human thoughts (21).

\section{METHODS}

In this study, a cross sectional and descriptive study design were exploited to identify the impacts of human values on the perception of ethical climate. The research was designed according to total population sampling. The study was conducted with randomly selected 178 volunteers out of 270 individuals working in a private hospital operating in Istanbul. The survey was carried out in four weeks period starting from March 2019.

The questionnaire applied in the study was formed by three sections in total. The first section examined socioeconomic characteristics, second section applied human values scale and the last section applied ethical climate scale.

Both of the scales employed in the study (human values scale and ethical climate scale) were already valid and reliable and widely used in the literature. Human values scale was introduced and validated by Dilmaç (2007). It is a Likert type scale that can be applied individually or in groups. It measures the human values by 42 items in six dimensions (i.e., Responsibility, Friendship, Peacefulness, Respect, Tolerance and Honesty). Higher scores of the scale imply better human values (22).

As for ethical climate scale, it was introduced by Schwepker (2001) and validated by Eren and Hayatoğlu (2011). It is also a Likert type scale measuring ethical climate. Increasing scores of the scale refer higher perceptions of the ethical climate (23).

Cronbach Alpha reliability tests were performed not only for the scales of human values and ethical climate perception and but also for the whole survey respectively. Accordingly, the calculated Cronbach Alpha values were 0.865, 0.912 and 0.858 respectively. Therefore, it was understood that the scales employed in the study were valid and reliable.

Finally, ordinary least squares regression was employed to understand the impact of human values on the ethical 
climate perception. The estimation formula can be illustrated as follows:

Ethical Climate Perception Pli $=\beta_{0}+\beta_{1}$ Human Values $_{i}+u_{i}$

where Ethical Climate Perception Pis $_{i}$ is outcome variable, $\beta_{0}$ is constant, Human Values $i$ is the explanatory variable whose impact is of interest, $\beta_{1}$ is the estimated impact and finally $u_{i}$ is the error term.

\section{RESULTS}

\subsection{Sociodemographic Characteristics of the Respondents}

Summary statistics regarding socioeconomic characteristics of the respondents are presented in Table 1. Accordingly, 83\% of the participants was female, $64 \%$ was married and $\% 67$ was over 25 years of age. In addition, $45 \%$ held high school or lower degree and $51 \%$ worked for five years or shorter. Finally, $34 \%$ of the participants did not have any children while $33 \%$ of them had one child.

Table 1. Sociodemographic Characteristics of the Respondents

\begin{tabular}{|c|c|c|c|}
\hline \multicolumn{2}{|l|}{ Variable } & $\mathbf{N}$ & $\%$ \\
\hline \multirow{3}{*}{ Gender } & Female & 148 & 83.1 \\
\hline & Male & 30 & 16.9 \\
\hline & Total & 178 & 100 \\
\hline \multirow{3}{*}{ Marital Status } & Married & 114 & 64 \\
\hline & Non-Married & 64 & 36 \\
\hline & Total & 178 & 100 \\
\hline \multirow{4}{*}{ Age } & $18-25$ & 58 & 33.3 \\
\hline & $26-35$ & 72 & 41.4 \\
\hline & $36-45$ & 44 & 25.3 \\
\hline & Total & 174 & 100 \\
\hline \multirow{5}{*}{ Educational Status } & High School or Below & 80 & 44.9 \\
\hline & Undergraduate & 20 & 11.2 \\
\hline & Graduate & 62 & 34.8 \\
\hline & Postgraduate & 16 & 9.1 \\
\hline & Total & 178 & 100 \\
\hline \multirow{5}{*}{ Duration of Service } & 5 years or Below & 90 & 51.1 \\
\hline & $6-10$ years & 48 & 27.3 \\
\hline & $11-15$ years & 20 & 11.4 \\
\hline & 16 years or above & 18 & 10.2 \\
\hline & Total & 176 & 100 \\
\hline \multirow{4}{*}{$\begin{array}{l}\text { The Number of } \\
\text { Children }\end{array}$} & 0 & 62 & 34.8 \\
\hline & 1 & 60 & 33.8 \\
\hline & 2 & 36 & 20.2 \\
\hline & 3 & 20 & 11.2 \\
\hline
\end{tabular}

\subsection{Descriptive Statistics Regarding the Scales}

Descriptive statistics of human values and ethical climate perception are presented in Table 2 below. Accordingly mean levels of human values and ethical climate perception were 3.88 and 3.83 respectively while standard deviations of them were 0.34 and 0.66 , respectively.
Table 2. Descriptive Statistics

\begin{tabular}{|l|l|c|c|c|c|c|c|c|}
\hline Number & Scale & Interval & Min. & Max. & X & S.D. & Skewness & Kurtosis \\
\hline 1. & $\begin{array}{l}\text { Human } \\
\text { Values }\end{array}$ & $1-5$ & 2.98 & 4.90 & 3.88 & 0.34 & 0.229 & 0.491 \\
\hline 2. & $\begin{array}{l}\text { Ethical } \\
\text { Climate }\end{array}$ & $1-5$ & 2.57 & 5.00 & 3.83 & 0.66 & 0.264 & -0.855 \\
\hline
\end{tabular}

X: mean, S.D..: standard deviation

\subsection{Variations}

In order to understand the variations in human values and ethical climate perception among genders and the individuals with different marital status, t-tests were performed in independent samples. The results are presented in Tables 3 and 4.

Table 3. The Differences According to Gender

\begin{tabular}{|l|c|c|c|c|c|c|}
\hline & Gender & $\mathbf{N}$ & Mean & S. D. & t & P \\
\hline \multirow{2}{*}{ Ethical Climate } & Female & 148 & 3.82 & 0.66 & \multirow{2}{*}{-0.381} & \multirow{2}{*}{0.751} \\
\cline { 2 - 6 } & Male & 30 & 3.86 & 0.68 & & \\
\hline \multirow{2}{*}{ Human Values } & Female & 148 & 3.87 & 0.32 & \multirow{2}{*}{-1.224} & \multirow{2}{*}{0.263} \\
\cline { 2 - 5 } & Male & 30 & 3.94 & 0.42 & & \\
\hline
\end{tabular}

Table 4. The Differences According to Marital Status

\begin{tabular}{|l|c|c|c|c|c|c|}
\hline \multirow{2}{*}{ Ethical Climate } & Marital Status & $\mathbf{N}$ & Mean & S. D. & t & P \\
\cline { 2 - 6 } & Non-Married & 114 & 3.94 & 0.66 & \multirow{2}{*}{3.157} & \multirow{2}{*}{0.002} \\
\hline \multirow{2}{*}{ Human Values } & Married & 64 & 3.62 & 0.63 & & \\
\cline { 2 - 6 } & Non-Married & 114 & 3.88 & 0.28 & \multirow{2}{*}{0.011} & \multirow{2}{*}{0.991} \\
\hline
\end{tabular}

Accordingly, it was identified that human values and ethical climate perception did not vary across genders. On the other hand, human values did not vary upon marital status while ethical climate perception was different among married and non-married samples.

One-way variance analysis (ANOVA) was employed to understand whether human values and ethical climate perception vary upon age while Kruskal Wallis test was performed for the variations upon educational status, the number of children and the duration of service. Accordingly, human values and ethical climate perception significantly differed according to age and the number of children, while there seemed no significant differences according to educational status. As for the duration of service, it was identified that human values significantly differed across the participants with different years of service while ethical climate perception was invariant. The results are presented in Tables 5-8.

Table 5. The Differences According to Age

\begin{tabular}{|l|c|c|c|c|c|c|c|}
\hline & $\begin{array}{c}\text { Age } \\
\text { Groups }\end{array}$ & N & Mean & S. D. & F & p & Difference \\
\hline \multirow{2}{*}{$\begin{array}{l}\text { Human } \\
\text { Values }\end{array}$} & $18-25$ & 58 & 3.78 & 0.38 & & & B $>A$ \\
\cline { 2 - 5 } & $26-35$ & 72 & 3.93 & 0.33 & 3.431 & 0.035 & \\
\cline { 2 - 5 } & $36-45$ & 44 & 3.92 & 0.28 & & & \\
\hline \multirow{2}{*}{$\begin{array}{l}\text { Ethical } \\
\text { Climate }\end{array}$} & $18-25$ & 58 & 3.61 & 0.62 & & & C $>$ A \\
\cline { 2 - 5 } & $26-35$ & 72 & 3.87 & 0.64 & 4.875 & 0.009 & \\
\cline { 2 - 5 } & $36-45$ & 44 & 4.00 & 0.70 & & & \\
\hline
\end{tabular}

$A=18-25 ; B=26-35 ; C=36-45$ 
Table 6. The Differences According to Educational Status

\begin{tabular}{|c|c|c|c|c|c|c|}
\hline & $\begin{array}{c}\text { Educational } \\
\text { Status }\end{array}$ & $\mathbf{N}$ & $\begin{array}{l}\text { Mean } \\
\text { Rank }\end{array}$ & $X^{2}$ & $\mathbf{P}$ & Difference \\
\hline \multirow{4}{*}{$\begin{array}{l}\text { Human } \\
\text { Values }\end{array}$} & High School & 80 & 88.85 & \multirow{4}{*}{0.508} & \multirow{4}{*}{0.917} & \multirow{4}{*}{-} \\
\hline & Undergraduate & 20 & 83.70 & & & \\
\hline & Graduate & 62 & 90.69 & & & \\
\hline & Postgraduate & 16 & 95.38 & & & \\
\hline \multirow{4}{*}{$\begin{array}{l}\text { Ethical } \\
\text { Climate }\end{array}$} & High School & 80 & 87.63 & \multirow{4}{*}{1.103} & \multirow{4}{*}{0.776} & \multirow{4}{*}{ - } \\
\hline & Undergraduate & 20 & 97.00 & & & \\
\hline & Graduate & 62 & 87.27 & & & \\
\hline & Postgraduate & 16 & 98.13 & & & \\
\hline
\end{tabular}

Table 7. The Differences According to the Number of Children

\begin{tabular}{|c|c|c|c|c|c|c|}
\hline & $\begin{array}{c}\text { The Number } \\
\text { of Children }\end{array}$ & $\mathbf{N}$ & $\begin{array}{c}\text { Mean } \\
\text { Rank }\end{array}$ & $\mathrm{X}^{2}$ & $p$ & Difference \\
\hline \multirow{4}{*}{$\begin{array}{l}\text { Human } \\
\text { Values }\end{array}$} & 0 & 62 & 93.31 & \multirow{4}{*}{22.155} & \multirow{4}{*}{0.000} & \multirow{4}{*}{$\begin{array}{l}D>A \\
D>B \\
D>C\end{array}$} \\
\hline & 1 & 60 & 144.70 & & & \\
\hline & 2 & 36 & 150.42 & & & \\
\hline & 3 & 20 & 198.50 & & & \\
\hline \multirow{4}{*}{$\begin{array}{l}\text { Ethical } \\
\text { Climate }\end{array}$} & 0 & 62 & 121.70 & \multirow{4}{*}{51.417} & \multirow{4}{*}{0.000} & \multirow{4}{*}{$\begin{array}{l}D>A \\
D>B \\
D>C \\
C>A\end{array}$} \\
\hline & 1 & 60 & 121.15 & & & \\
\hline & 2 & 36 & 145.08 & & & \\
\hline & 3 & 20 & 190.70 & & & \\
\hline
\end{tabular}

$A=0 ; B=1 ; C=2 ; D=3$

Table 8. The Differences According to the Duration of Service

\begin{tabular}{|c|c|c|c|c|c|c|}
\hline & $\begin{array}{c}\text { The Duration of } \\
\text { Service }\end{array}$ & $\mathbf{N}$ & $\begin{array}{l}\text { Mean } \\
\text { Rank }\end{array}$ & $x^{2}$ & $\mathbf{p}$ & Difference \\
\hline \multirow{4}{*}{$\begin{array}{l}\text { Human } \\
\text { Values }\end{array}$} & 5 years of below & 90 & 77.48 & \multirow{4}{*}{14.982} & \multirow{4}{*}{0.002} & \multirow{4}{*}{$\begin{array}{l}B>C \\
B>A\end{array}$} \\
\hline & $6-10$ years & 48 & 111.38 & & & \\
\hline & $11-15$ years & 20 & 78.00 & & & \\
\hline & 16 years or above & 18 & 94.28 & & & \\
\hline \multirow{4}{*}{$\begin{array}{l}\text { Ethical } \\
\text { Climate }\end{array}$} & 5 years or below & 90 & 78.43 & \multirow{4}{*}{7.484} & \multirow{4}{*}{0.058} & \multirow{4}{*}{--} \\
\hline & $6-10$ years & 48 & 101.21 & & & \\
\hline & $11-15$ years & 20 & 95.10 & & & \\
\hline & 16 years or above & 18 & 97.61 & & & \\
\hline
\end{tabular}

$A=5$ years of below; $B=6-10$ years; $C=11-15$ years; $D=16$ years or above

A post-hoc test was performed to identify the differences among age groups in detail. As a result, it was identified that average human values scores of the participants at $18-25$ years of age was significantly lower compared to their older counterparts at 26-35 years of age. Additionally, average ethical climate perception scores of the participants in 3645 age group was significantly higher in comparison with the participants in 18-25 age group.

A post-hoc test was also exploited to identify the differences of human values among the participants with different years of service in detail. Accordingly, average human values scores of the participants with 6 to 10 years of service was significantly higher than the average scores of (i) participants with 5 years of service or shorter and (ii) participants with 16 years of service or longer.

\subsection{Correlations Between Human Values and Ethical Climate Perception}

The correlation between human values and ethical climate perception is presented in Table 9. There was a positive, linear and weak correlation $(r=0,211, p<0,001)$ between human values and ethical climate perception.

Table 9. Correlations Between Human Values and Ethical Climate Perception

\begin{tabular}{|l|l|l|l|}
\hline \multicolumn{2}{|l}{ Variables (N=178) } & Human Values & Ethical Climate \\
\hline \multirow{2}{*}{ Human Values } & $\mathrm{R}$ & \multirow{2}{*}{1} & $0.211^{* *}$ \\
\cline { 2 - 3 } & $\mathrm{P}$ & & 0.000 \\
\hline \multirow{2}{*}{ Ethical Climate } & $\mathrm{R}$ & $0.211^{* *}$ & 1 \\
\cline { 2 - 3 } & $\mathrm{P}$ & 0.000 & 1 \\
\hline
\end{tabular}

${ }^{* *}$ r 0.001 significance level

\subsection{The Impact of Human Values on Ethical Climate Perception}

Impact analysis of human values on ethical climate perception was performed. Ordinary least squares regression was employed to understand the impact on the perception of ethical climate. The results are presented in Table 10. Accordingly, human values had statistically significant impacts on ethical climate perception $(p<0,001)$. It was understood that one unit of increase in human values scores was associated with approximately 0,2 increase in the scores of ethical climate perception. According to the model which was also understood that statistically significant $(F=8,209$, $p<0,01)$, human values can identify almost $5 \%$ of total variance of ethical climate perception $\left(R^{2}=0,045\right)$.

Table 10. Impact Analysis of Human Values for Dependent Variable of Ethical Climate Perception

\begin{tabular}{|l|l|l|l|l|l|}
\hline Variables & B & Standard Deviation & Beta & T & P \\
\hline Constant & 2.232 & 0.457 & & 4.887 & 0.000 \\
\hline Ethical Climate & 0.412 & 0.117 & 0.211 & 3.516 & 0,001 \\
\hline
\end{tabular}

$N=178, R=0.211, R^{2}=0.045$, Adjusted. $R^{2}=0.039, F=8.209, p<0.01$

\section{DISCUSSION}

The issues about ethical applications are of interest all over the world. In recent years, unethical behaviours have become an important issue especially in the fields of management. The formal or informal incorporation of morality, human values and ethics into daily lives can be the solution to any problem (24).

An ethical climate is critical to overcome unethical practices in health sector. By originating from the relationship between ethical values and human values, the study was designed to contribute to understanding of improving ethical climates. The study was based on the hypothesis that better human values are associated with improved ethical climates.

Human values have important roles in various things in a society. Wolf et al. (2020) exhibit that human values are 
important in tackling with COVID-19 spread. Accordingly, cross-cultural agreement on the importance of human values demonstrate that human values are well placed to develop and adapt effective global interventions to tackle with the spread (25). Crowe (2020) states that human values have notable impacts on human health (26). Several studies in the literature (27-29) suggest that human values are associated with the improvements in professional ethics. In this study, it was identified that human values have important contributions in improving ethical climate. The findings are also important as they provide intuitions for a competitive environment like private hospitals.

Ethical climate is a fundamental aspect of organisational life affecting both individuals and organisations (30). There have been studies examining ethical studies in the literature. Tehraninesat et al. (2020) investigate ethical climate among nurses and conclude that professional values and ethical climate have significant associations with the quality of life (31). Since the ethical behaviours of the employees working at the forefront of customer relations are important, the organisations are required to understand how a strong ethical climate affects attitudes and behaviours in an organisation (32). Yasin et al. (2020) and Nurtatin (2020) demonstrate that improved ethical climate leads to reduced intentions to quit in the organisations. In this study, it was detected that the ethical climate improves in organisations where humanitarian values improve. Hence, the layoffs will decrease in the organisations where humanitarian values are improved $(33,34)$.

In this study, it was identified that human values and ethical climate perception do not vary according to gender. The finding confirms Karababa ve Dilmaç (2015) suggesting that human values have important roles in experiencing and expressing anger and do not vary upon gender. On the contrary, the finding conflicts with Karagözoğlu (2017) indicating that human values of artisans differ across age and gender groups $(1,35)$.

It was observed that human values did not vary upon marital status while ethical climate perception was different among married and non-married samples. In addition, human values and ethical climate perception significantly differed according to age and the number of children. Çalışkur et al. (2012) demonstrate a positive and weak relationship between purposeful and instrumental values, and state that "honesty, family security and peace of mind" values are common values seen in all groups. In addition, they detect that participants in different age and gender groups have different purposeful and instrumental values (3).

There were no significant differences according to educational status. It was also identified that human values significantly differed across the participants with different years of service while ethical climate perception was invariant.

Jalali (2013) identify that ethical climate is an important factor affecting work performance and affects the quality of patient care (36). Akdoğan and Demirtaş (2014) demonstrate that ethical leadership directly and indirectly affect ethical climate sub-dimensions (except independence dimension of ethical climate) (37). They add that organizational political perceptions play a mediating role in the indirect effect of ethical leadership (37). Humphries and Woods (2015) conclude that patient flow initiatives and budget policies implemented by institutions have detrimental effects on the ethical practices of nurses. In addition, they indicated that nurses experience moral distress and hence patient care was negatively affected as a result of such policies (38).

\section{CONCLUSION}

This study examined the impact of human values on the perception of ethical climate. To do this the study employed parametric and nonparametric methods using the data of 178 volunteers working in a private hospital operating in İstanbul. By doing this, the study aimed to provide intuitions towards ethical climate in a competitive environment.

The study also investigated the socioeconomic factors affecting human values and ethical climate perception. Identifying such factors is important since human values and ethical climate have important roles in organisational relations and structures (16).

The study observed that human values have impacts on ethical climate perception. It was identified that better human values were associated with better perception of ethical climate implying that the people with better human values were more careful about ethical rules. Further studies investigating the effects of human values on ethical cultures will make important contributions to broader literature about human values and ethics.

The findings of the study are important to understand the motivations of ethical climate in a competitive atmosphere. It is believed that further studies investigating ethical climates in public and private organisations comparatively will also contribute to the literature of ethical climates.

\section{REFERENCES}

[1] Karagözoğlu N. Esnafların sahip olduğu insani değerler, Journal of Social and Humanities Sciences Research, 2017; 4(4): 649660. (Turkish)

[2] Ulusoy K, Dilmaç B. Değerler eğitimi. Ankara, PEGEM Akademi. 2018.

[3] Çalışkur A, Demirhan A, Bozkurt S. Değerlerin belirli meslek alanları ve demografik değişkenlere göre incelenmesi. Süleyman Demirel Üniversitesi îktisadi ve İdari Bilimler Fakültesi Dergisi, 2012; 17(1): 219-236. (Turkish)

[4] Kluckhohn C. Values and value-orientations in the theory of action: an exploration in definition and classification, in Toward a general theory of action: Theoretical Foundations for the Social Sciences, eds. Parsons T, Shils E. (New York, NY: Harper), 1951; 388-433.

[5] Türe Yılmaz A, Demirsoy N. Bir kamu hastanesinde çalışan hemşirelerin profesyonel değerleri ve etkileyen faktörler. 
Akademik Sosyal Araştırmalar Dergisi, 2018; 6(66): 108-120. (Turkish)

[6] Kuşdil E, Kağıtçıbaşı Ç. Türk öğretmenlerin değer yönelimleri ve Schwartz değer kuramı. Türk Psikoloji Dergisi, 2000; 15(45): 59-76. (Turkish)

[7] Büyükyıldırım I, Dilmaç B. Siber mağdur olmanın insani değerler ve sosyodemografik değişkenler açısından incelenmesi. Değerler Eğitimi Dergisi, 2015; 13(29): 7-40. (Turkish)

[8] Erdem AR. Bilim insanı yetiştirmede etik eğitimi. Yükseköğretim ve Bilim Dergisi, 2012; 2(1): 25-32. (Turkish)

[9] Şenel Tekin P. Tıp sekreterliğinde mesleki etik. 7. Ulusal Büro Yönetimi ve Sekreterlik Kongresi. 2008; 101-110. (Turkish)

[10] Atlığ NS. İş etiği, sosyal sorumluluk ve ilaç sektöründen uygulamalar. Yıldız Teknik Üniversitesi, Yüksek Lisans Tezi, 2006. (Turkish)

[11] Büyükbeşe T, Bakan I, Erşahan B, Sözbilir F. Ethical climate, job satisfaction and mobbing. Türk\&islam Dünyası Sosyal Araştırmalar Dergisi/The Journal of Turk \& Islam World Social Studies 2017; 4(10): 92-132. (Turkish)

[12] Peterson DK. Deviant workplace behavior and the organization's ethical climate. Journal of Business and Psychology 2002; 17(1): 47-61.

[13] Şahin B, Dündar T. Sağlık sektöründe etik iklim ve yıldırma (mobbing) davranışları arasındaki ilişkinin incelenmesi. Ankara Üniversitesi SBF Dergisi 2011;66(1):129-159. (Turkish)

[14] Hanel PHP, Litzellachner LF, Maio GR. An empirical comparison of human value models. Frontiers Psychology. 2018; 9: 1-14. doi: 10.3389/fpsyg.2018.01643

[15] Holmes V, Tang S, Foley T, Rowe M. Australian legal practice: ethical climate and ethical climate change. New Directions for Law in Australia. 2017; 462.

[16] Singh AK. Role of human value and ethics in organizational leadership. International Journal of Research and Analytical Reviews, 2019; 6(1), 1210-1216.

[17] Dodd R, Achen RM, Lumpkin A. Servant leadership and its impact on ethical climate. The Journal of Values-Based Leadership: 2018; 11(1): 1-22.

[18] Soffian L, Ismail AB. Ethical climate as a determinant of organizational commitment. International Journal of Asian Social Science, 2018; 8(8): 534-539.

[19] Mitonga-Monga J, Cilliers F. Ethics culture and ethics climate in relation to employee engagement in a developing country setting. Journal of Psychology in Africa, 2015; 25(3): 242-249.

[20] Amer AB. The ethics of veracity and it is importance in the medical ethics. Open Journal of Nursing, 2019; 9(1): 194-198.

[21] Oppong S. When the ethical is unethical and the unethical is ethical: Cultural relativism in ethical decision-making. Polish Psychological Bulletin, 2019; 50(1): 18-28.

[22] Dilmaç B. Bir grup fen lisesi öğrencisine verilen insani değerler eğitiminin insani değerler ölçeği ile sınanması. Selçuk Üniversitesi, Doktora Tezi, 2007. (Turkish)
[23] Eren SS, Hayatoğlu Ö. Etik iklimin satış elemanlarının iş tutumlarına ve iş performanslarına etkisi: illaç sektöründe bir uygulama, ZKÜ Sosyal Bilimler Dergisi, 2011; 7(14): 109-128. (Turkish)

[24] Basu D, Chaktaborty S. A textbook on human values and ethics. New Delhi Publishers, 2020.

[25] Wolf LJ, Haddock G, Manstead ASR, Maio GR. The importance of (shared) human values for containing the COVID-19 pandemic, British Journal of Social Psychology, 2020; 59(3): 618-627.

[26] Crowe J. What is welness? the role of human values. Alternative Law Journal, 2020; https://doi. org/10.1177\%2F1037969X20954872

[27] Velusamy J. Professional ethics and human values, I-Manager Publications, 2017.

[28] Shukla T, Yadav A, Singh Chauhan G. Professional ethics and human values, Cengage Learning International, 2018, I.

[29] Manoharan C, Birundha B. Human values and professional ethics. Shanlax International Journal of Management, 2019; 7(2): 65-69.

[30] Teresi M, Pietroni DD, Barattucci M, Giannella VA, Pagliaro S. ethical climate(s), organizational identification, and employees' behavior. Front Psychol. 2019; 10: 1356. doi: 10.3389/fpsyg.2019.01356

[31] Tehranineshat B, Torabizade K, Bijani, M. A study of the relationship between professional values and ethical climate and nurses'professional quality of life in iran. International Journal of Nursing Sciences, 2020; 7: 313-319.

[32] Friend SB, Jaramillo F, Johnson JS. Ethical climate at the frontline: A meta-analytic evaluation. Journal of Service Research, 2020; 23(2): 116-138.

[33] Yasin R, Obsequio Namoco, S, Jauhar, J, Abdul Rahim NF, UI Zia, N. Responsible leadership and ethical climate. Social Responsibility Journal, 2020; https://doi.org/10.1108/SRJ-032020-0092

[34] Nurtati N, Yanti N, Trianindi Untari M. Turnover intention: The impact of ethical climate. job satisfaction and organizational commitment. Journal of Management and Business, 2020; 3(1): 75-89.

[35] Karababa A, Dilmaç B. Ergenlerdeki insani değerlerin sürekli öfke ve öfke ifade biçimlerini yordamadaki rolü. İlköğretim Online, 2015; 14(3): 1149-1158. (Turkish)

[36] Jalali T, Kalantari S, Hekmat Afshar M, Joubary LM. The nurse's perception from the hospital ethical climate. Jentashapir 2013;4(1): 65-72.

[37] Akdoğan A, Demirtaş Ö. Etik liderlik davranışlarının etik iklim üzerindeki etkisi: Örgütsel politik algılamaların aracı rolü. AKÜ iiBF Dergisi, 2014; XVI(1): 107-123. (Turkish)

[38] Humphries A, Woods M. A study of nurses' ethical climate perceptions: compromising in an uncompromising environment. Nursing Ethics, 2015; 22(1): 1-12. 